\title{
交流電場条件による粒子分散型機能性流体の流動特性
}

\section{Effect of Alternating Electric Field Conditions on Flow Characteristics of Particle Dispersion Type Functional Fluid}

\author{
○正 小原弘道(首都大), 井畑遼亮（本田技研），河合祐輔(首都大)， \\ 正 田代伸一(首都大)，正 松平晏明(首都大)
}

\author{
Hiromichi OBARA, Tokyo Metropolitan University, 1-1 Minami Osawa, Hachioji, Tokyo, Japan \\ Ryosuke IBATA, HONDA Honda Motor Co., Ltd. \\ Yusuke KAWAI, Under Graduate School of Tokyo Metropolitan University, \\ Shinichi TASHIRO, Tokyo Metropolitan University \\ Yasuaki MATSUDAIRA, Tokyo Metropolitan University
}

\begin{abstract}
This study investigated the effect of the alternating electric field conditions on the generating mechanism of the specific flow structures of the particle dispersion type functional fluid, which consists of suspended micro scale diamond particles in insulated silicon oil. These specific flow structures contribute actively to a polishing process and to the development of micro fluidic devices. One of the specific flow structure is rotational flow structure formed under high-electric-field intensity and low-frequency conditions. This rotational flow structure is induced by the local accreted flows indicated as the characteristic velocity. The electric field waveform and frequency affects the movements of the local accreted particle that induce the accreted flow between the electrodes. The working time of the electric field is important to generate the accreted flow and the inclination of the electric filed dose not contribute to generate the accreted flow.
\end{abstract}

\section{Key Words: Micro Vortex, Forced Convention, Polishing, Micro-PIV, Cluster, Diamond Particles, EHD}

\section{1. 緒言}

様々な応用が期待される機能性流体の一つの適用例とし てダイヤモンド粒子分散型機能性流体を援用した新しい研 磨技術が考案(1)され，特定の電場条件下に扔いて形成される 特異な流動が研磨特性向上に大きく寄与していることが報 告(1)(2)されている. この特異な流動特性を評価し，流動形成 機構を解明することは, 研磨加工特性向上のみならず新しい マイクロ流体デバイスの開発のためにも大変興味深い.この 特異な流動は, 高電場強度および低周波数の特定の電場条件 下において交流電場印加に対応して同一面内に一定の間隔

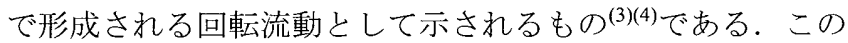
回転流動は交流印加電場の極性変化に位相遅れを有して誘 起される加速流動により形成される(5)ことが明らかにされ たものの，流動の形成機構については明らかにされていない. また，これらの報告の中で，印加電場周波数変化に伴い，流 動特性が変化することが示されたものの, 周波数変化にとも なう流動特性の変化の要因や印加電場波形の流動形成への 影響については未解明なままである. 波形形状や長さなどを 変化させ流動特性の評価を行うことで, 交流電場条件の流動 形成への影響を明らかにすることができるだけでなく，特異 な流動の流動形成機構を解明できると考えられる.

以上の背景から本報では, 粒子分散型機能性流体に誘起さ れる回転流動形成機構解明のために, 交流電場条件変化, 特 に周波数変化に対応する電場の作用する時間ならびに電場 の勾配に対応する印加波形の立ち上がり角度に着目し, マイ クロ PIV 計測により形成される流動特場特性を明らかにす る.さらに，流動場特性を評価する指標として速度場情報か ら得られる極大速度情報を用い, 交流電場条件変化による流 動特性変化を明らかにし, 粒子の分散特性との相関を含め, 流動形成機構を解明する。

\section{2. 実験装置および方法}

実験装置は, マイクロ流路, 高電圧供給システム, マイク 口画像計測システムから構成され，マイクロ流路は, 透明ガ ラス板上に 2 枚の銅板を電極間距離 $d=1.2 \mathrm{~mm}$ で対向配置,
接着固定した電極間とした。交流印加電場は波形生成装置, 高電圧アンプから構成される高電圧供給システムにより生 成した。マイクロ画像計測システムは, 光学系として顕微鏡 (対物レンズ 5 倍, リレーレンズ 1.5 倍), 光学フィルタ, CCD カメラならびに光源から構成される. 速度場情報は, PIV 計測を用い, CCD カメラで取得した粒子画像より相互相 関法により取得した。実験は，湿度を管理した環境下におい て，十分に混合した供試流体を流路内に滴下し，図 1 (a)に示 すように電場を印加することで行った，供試流体は，電気絶 縁性を有するシリコンオイル（信越化学工業, KF-96 動粘度 $v=100 \mathrm{~mm}^{2} / \mathrm{s}, 25^{\circ} \mathrm{C}$ ) を溶媒とし, 粒径 2 4 $\mu \mathrm{m}$ の人夕゙ イヤモンド粒子を分散させた粒子分散型機能性流体を用い, 溶媒に対する分散粒子の濃度は $c=1 \mathrm{wt} . \%$ とした。なお, PIV 計測用としての蛍光粒子（粒子径 $3 \mu \mathrm{m}$, 蛍光波長 $612 \mathrm{~nm}$ ) も併せて混合しているが，本実験条件範囲では蛍光粒子混入

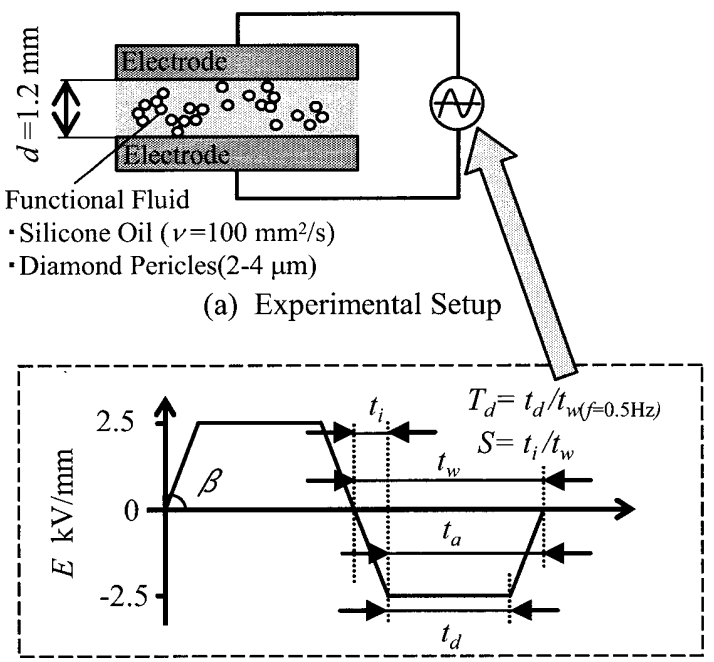

(b) Waveform of Alternating Electric Field

Fig. 1 Experimental Conditions 
による流動様相特性の変化は無いことを確認している. 座標 系は電場と垂直方向に $x$ 軸, 電場と平行に $y$ 軸とし, 電極間 中央を原点とした。

図 1(b)に印加電場波形形状と各定義を示す. 電場勾配を示 寸指標として電場強度が 0 から最大の電場強度 (本報告では $\pm 2.5 \mathrm{kV} / \mathrm{mm}$ ）に到達するまでの時間を立ち上がり時間 $t_{i}$ と し，その時間と到達寸る電場強度の正接を電場の立ち上がり 角 $\beta=\arctan \left(E / t_{i}\right)$ として定義した。また，電場強度が一定 到達し，その電場強度が電極間に作用する時間を，基準波形 の作用時間により無次元化した定電場作用時間 $T_{d}$ (以下，定 電場時間）として定義した。あわせて電場波形形状を表す係 数として，電場波形形状係数 $S=t_{i} / t_{w}$ と定義した．なお，波 形の半周期を $t_{w}$ とした。 なお，基準波形は， $E=2.5 \mathrm{kV} / \mathrm{mm}$, $f=0.5 \mathrm{~Hz}$ の電場勾配を示寸立ち上がり角度 $\beta=90^{\circ}$ となる 矩形波形とし，このときの基準となる定電場作用時間は $1 \mathrm{~s}$ である. 実験条件は, 電場強度を $E=2.5 \mathrm{kV} / \mathrm{mm}$ 一定とし, 波形形状条件を変化させて定電場時間 $T_{d}$ と電場勾配角 $\beta$ を変 化させた.ここで, 各電場条件における流動特性の評価には, 流動代表速度ならびに極大速度を用いた. 流動代表速度 vは， 電場印加により誘起される流動特性を空間的に代表する速 度情報として, 計測断面内における正負方向のそれぞれの絶 対值の大きい速度情報と定義した。 また，印加電場との同期 計測による擬似連続速度場情報から取得される流動代表速 度の時間変化における極大值を極大速度 $v_{M}$ として定義した.

\section{3. 実験結果および考察}

3-1 電場波形形状変化による速度場特性 図 2 に印加電場 の波形形状の変化による流動場特性変化を速度べクトル分 布ならびに渦度分布により示す. 電場周波数 $f=0.5 \mathrm{~Hz}$ 一定と して，電場勾配を示寸電場立ち上がり角 $\beta$ ならびに定電場時

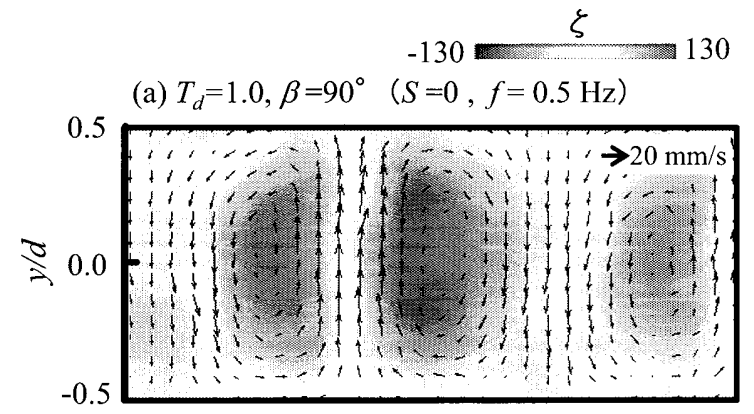

(b) $T_{d}=0.6, \beta=86^{\circ} \quad(S=0.2, f=0.5 \mathrm{~Hz})$

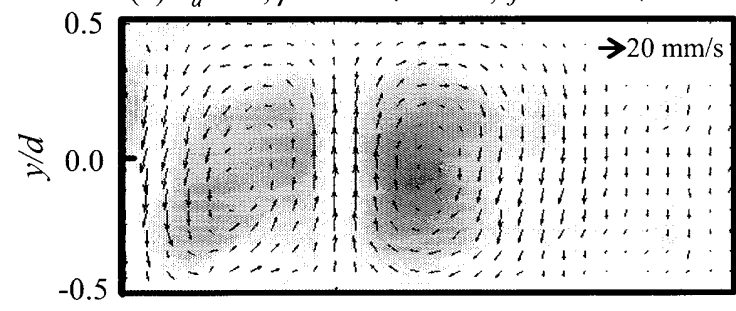

(c) $T_{d}=0.4, \beta=82^{\circ} \quad(S=0.4, f=0.5 \mathrm{~Hz})$

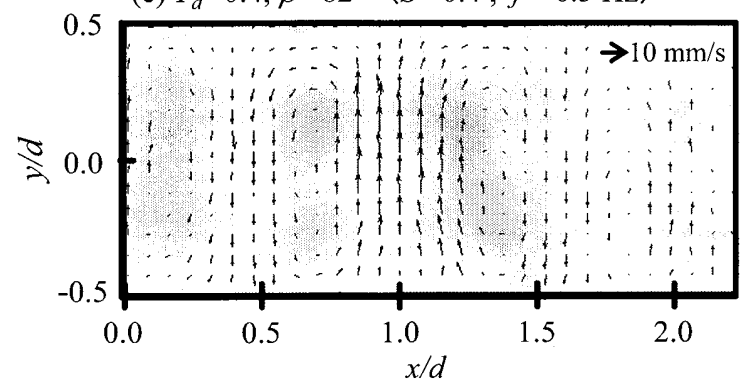

Fig. 2 Velocity Vector and Vorticity Map
間を変化させた結果である.いずれも, 回転流動が最大に発 達する位相における分布を示しており，(c)に関しては，2倍 のスケールでベクトルを表示している. また，それぞれの図 には模式的に印加電場波形を表示している. 基準波形 (a)に おいては，それぞれの電極から局所的に誘起される加速的な 流動である加速流動が示されており，これらの流動の間には 電極間の同一面内において回転方向の異なる回転流が交互 に形成される回転流動が形成されている.渦度分布において も，この回転流動に対応した正負の渦度分布が示されている. 基蕉波形に比し若干 の電場勾配 $(\beta=86 \mathrm{deg})$ を有する(b)にお いては, それぞれの電極から局所的に誘起される流動は基準 波形同様に形成されており, 同様に回転流動も形成されてい る. 一方, さらに電場勾配は緩やかになり, 定電場時間も短 い(c)においては, 局所的な加速流動は形成されてはいるもの の, 誘起される速度は小さく, 対応した回転流動も弱く, 正 負の渦度分布も他に比して小さい. 波形形状が変化すること により, 同電場強度が作用しているにもかかわらず誘起され る流動に変化が示された。このことから, 電場波形条件が流 動形成に影響を与えていると考えられる.

図 3 は各位相における流動代表速度をそれぞれの電場波形
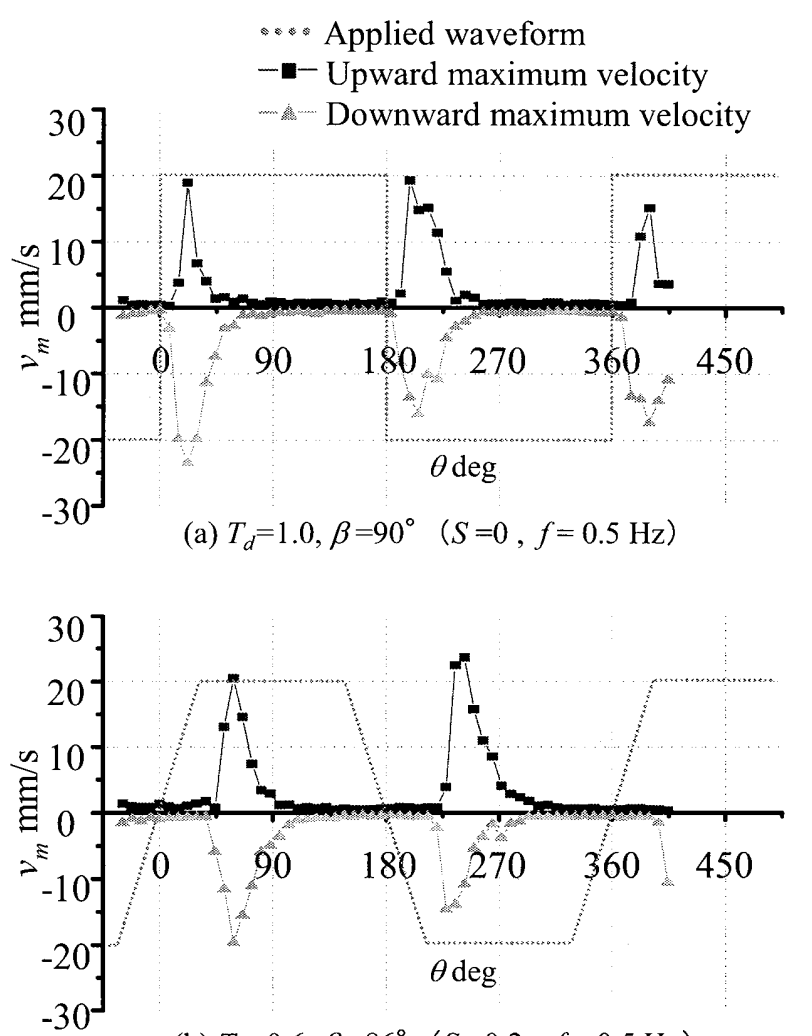

(b) $T_{d}=0.6, \beta=86^{\circ} \quad(S=0.2, f=0.5 \mathrm{~Hz})$

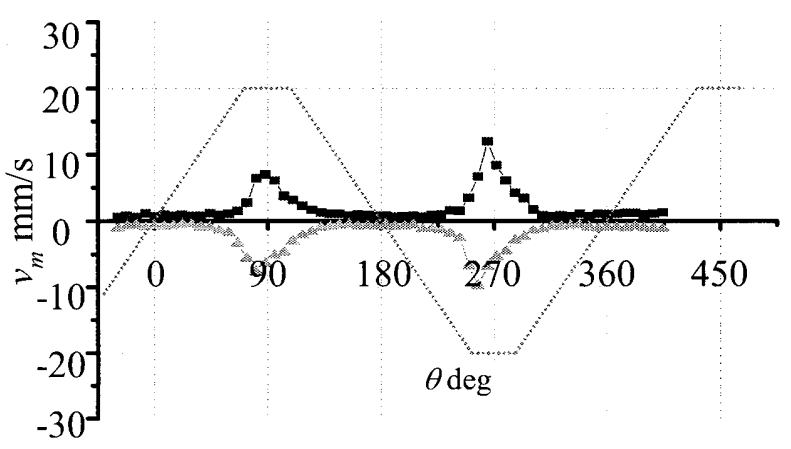

(c) $T_{d}=0.4, \beta=82^{\circ} \quad(S=0.4, f=0.5 \mathrm{~Hz})$

Fig. 3 Time history of Characteristic Velocity 
条件に関して示す. 電場波形条件は, 前述の速度場特性と同 様である. 基準波形(a)においては，速度場情報と同様に，電 場極性変化後に急激に増速し, 極大速度を示した後にすみや かに減速し, 次の電場極性変化まで大きな速度は示さない回 転流動を形成する明瞭な局所的な流動が誘起されており，こ の流動に対応した流動代表速度分布が示されており, 若干の 電場勾配を有する $(\mathrm{b})$ においても基準波形における分布と同 様に, 加速度を有して変化する速度変化が示されており, そ の極大速度も基準波形のものとほぼ同程度となっている。一 方, さらに電場勾配が緩やかで定電場時間の短い波形条件(c) においては，流動代表速度の変化は急峻ではなくなり，また その極大速度も他に比して半分以下となっている. 電場波形 条件変化にともない, 誘起される流動は大きく変化しており, 流動形成は電場波形条件により左右されると考えられる. 以 降では，電場勾配ならびに，定電場時間それぞれに着目し， 回転流動形成に重要な役割を果たす局所的に形成される加 速流動特性に関して, 特にこの極大速度に対する電場条件変 化の影響に関して議論する。

3-2 電場勾配・定電場時間の影響 図 4 に電場勾配を示す電 場立ち上がり角 $\beta$ の変化による極大速度 $v_{M}$ を示す. 電場勾 配の影響を明らかにするために, 電場強度を $E=2.5 \mathrm{kV} / \mathrm{mm}$ な らびに定電場時間 $T_{d}=1.0$ 一定として電場勾配 $\beta=56^{\circ} \sim 90^{\circ}$ を変化させた場合の極大速度を示寸．立ち上がり角 $\beta=76$ 90 ○においては，立ち上がり角によらずほぼ同程度の極大 速度が示されている.いずれの電場勾配においても回転流動 形成に必要な極大速度が誘起されており，この範囲内の電場 勾配の差異による影響は無いと考えられる。 寸なわち, 回転 流動形成に寄与する加速流動は, 電場の極性が変化した後の 短い時間の間に形成されるが，電場勾配として示される急峻 な電場変化によって形成されるものではないと考えられる. ただし, 非常に緩やかな変化となる $\beta=56$ 。 に関しては, 他 の勾配に比し誘起される極大速度は $1 / 2$ 程度に小さくなって いる。これは，極大速度に対応する回転流動が形成され最も 発達した位相が, 定電場強度となる $E=2.5 \mathrm{kV} / \mathrm{mm}$ 一移行途中 の印加電場強度 $E=1.8 \mathrm{kV} / \mathrm{mm}$ 程度の段階で流動が誘起され ており，流動形成に作用した電場強度が低いために他の条件 に比し極大速度が低く示されたためと考えられる。このこと は別の側面から考えれば, 電場勾配がかなり緩やかであって も回転流動形成に必要な加速流動を誘起することを示して おり, 電場勾配以外の要因が流動を誘起に支配的な影響を与 えていることが考えられる.

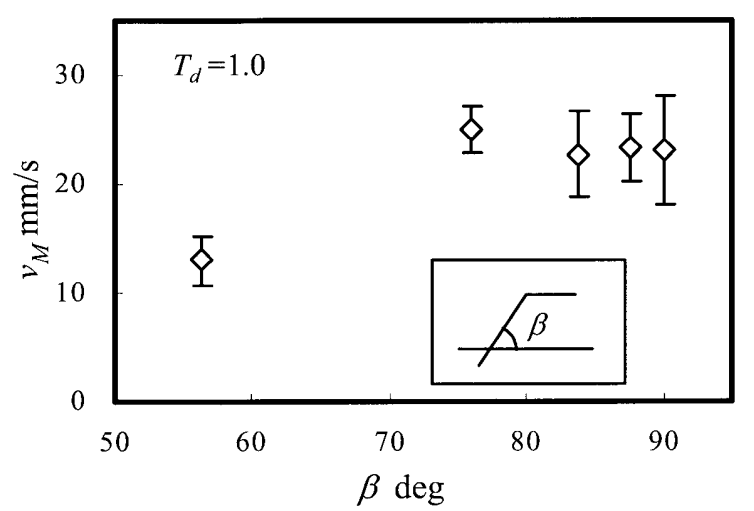

Fig. 4 Electric Field Gradient Effect on Maximum Velocity

図 5 に定電場時間 $T_{d}$ が変化した場合における流れ場を代 表する流動代表速度 $v$ の時間変化を示す.なお，ここでは， 定電場時間の影響を明らかにするために矩形波 $\left(\beta=90^{\circ}\right)$ を用い, 周波数変化により定電場時間を変化させた結果を示 す. $T_{d}=0.5,1.0,5.0$ は回転流動の形成が確認されている
条件である. 速度はいずれも $22 \mathrm{~mm} / \mathrm{s}$ 程度を有している. 電 場極性変化後にのほぼ同時刻においていずれの条件におい ても極大速度を示す。また, 極大速度到達後は, 定電場時間 に関係なく同様に速度の減衰を示す。一方, 往復流動が観察 される条件である $T_{d}=0.25,0.33$ においては, 極大速度は小 さく $15 \mathrm{~mm} / \mathrm{s}$ 以下になり, 十分な極大速度が誘起されていな い. 定電場時間変化によって誘起される速度特性に変化が 示されており，定電場時間が流動形成に影響を与えていると 考えられる。

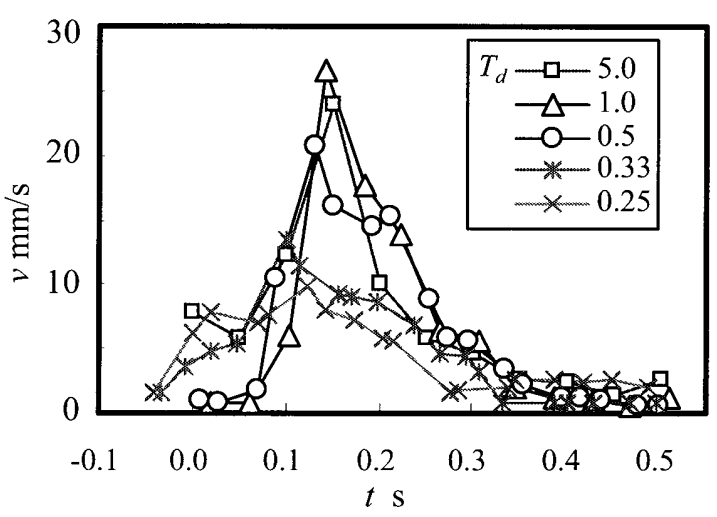

Fig. 5 Time History of Characteristic Velocity

図 6 に定電場時間 $T_{d}$ と極大速度 $v_{M}$ の関係を示す. (a)は図 5 に示した条件と同様に矩形波 $\left(\beta=90^{\circ}\right)$ を用い，周波数変 化により定電場時間を変化させた結果である。また，(b)にお いては，極大速度が急激に変化する 1.0 までの定電場時間に 着目し, (a)で示した波形を矩形波に固定し, 周波数を変化さ せて $T_{d}$ を変化させた結果(1), 周波数を固定し波形形状係数 を変化させて $T_{d}$ を変化させた結果(2), 定電場時間を固定し

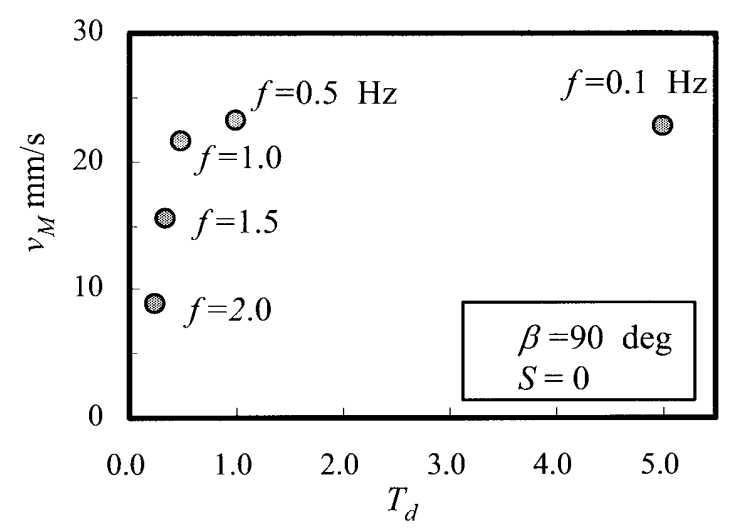

(a) Frequency Dependence of Maximum Velocity

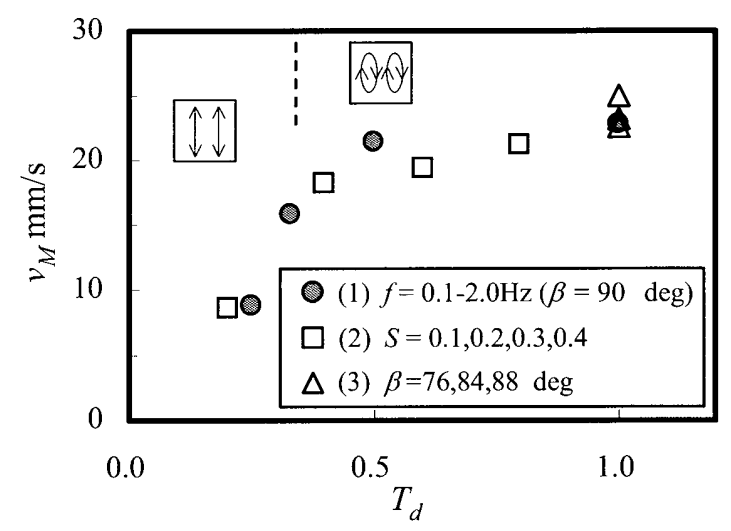

(b) Working Time of Constant Electric Field

Fig. 6 Constant Electric Field Time Effect on Maximum Velocity 
電場勾配変化させた結果(3)を示す. (a)では, 回転流動の形 成が確認されている条件である $T_{d}=0.5,1.0,5.0$ においては, 速度はいずれも $22 \mathrm{~mm} / \mathrm{s}$ 程度を有している。一方, 往復流動 が観察される条件である $T_{d}=0.25,0.33$ においては，極大速 度は $15 \mathrm{~mm} / \mathrm{s}$ 以下になり, 十分な極大速度が誘起されていな い. $T_{d}=0.25 \sim 0.5$ にかけて極大速度は急激に増加し, $T_{d}=0.5$ 以降は一定の分布となっている. (b)では，(2),(3)の条件の場 合を含めたすべての条件においても，電場勾配を一定とした (a)に示された特性と同様に, 短い定電場時閒においては極大 速度は小さく, 定電場時間の増加に伴い急激に増加を示し, 漸近する.このことは，どのような電場波形条件においても 定電場時閒が短い場合には, 誘起される極大速度も小さくそ れに対応する加速流動は弱く，また，定電場時間が増加する ことによって誘起される極大速度は上昇し, 一定以上の定電 場時間においては, 誘起される極大速度は漸近し, 十分な速 度を有する加速流動が形成されると考えられる。すなわち, 回転流動形成には，十分な定電場時間が必要であり，十分な 定電場時間が作用することによって十分な速度を有する加 速流動形成が形成され，これによって回転流動が形成される と考えられる。

3-3 電場波形条件による粒子分散特性 図 7 に電極極近傍 部における粒子の分散様相を示す.いずれも, 流動が誘起さ れる直前の様相である. 定電場時間が長い基準波形(a)におい ては, 電極近傍には鎖状に連なる粒子が, 多数示されている. これらの粒子は, 図示は割愛しているが, 電場極性が反転し, その後に局所的な加速流動が形成され, 流動が減哀した後に, 徐々に低速度で電極側に誘引され，流動形成前に図示した様 相となる。一方，定電場時間の短い(b)に执いては，電極近傍 に誘引される粒子量は少なく, 流動形成を左右する定電場時 間は電極近傍に誘引される粒子量に影響を与えているので はないかと考えられる。

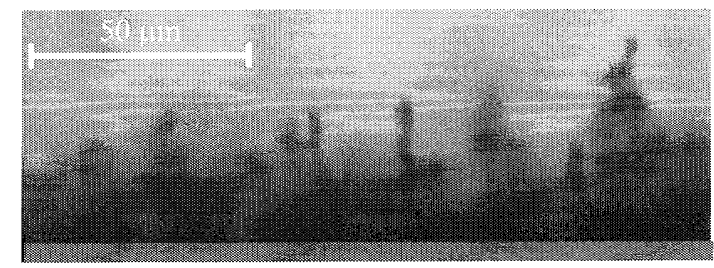

(a) $T_{d}=1.0, \beta=90 \mathrm{deg}(S=0, f=0.5 \mathrm{~Hz})$

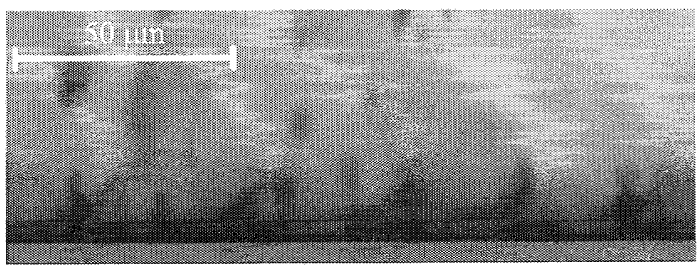

(b) $T_{d}=0.25, \beta=90 \mathrm{deg}(S=0, f=2.0 \mathrm{~Hz})$

Fig. 7 Concentration of Particles near Electrode

表 1 に電極近傍における粒子の分散特性を各電場条件に関 して整理した表を示す. 画像観察結果から得られた電極近傍 部の粒子量の多少を記号で示し, 多, 中, 少を $\bigcirc, \triangle, \times$ と した。 また，流動観察で得られた各電場条件による流動様相 を凡例にて示している.電極に誘引される粒子量が多い条件 (a) (c)においては，いずれも回転流動が形成され，粒子量が 少ない条件(e)においては, 往復流動となり，前述のように誘 起される極大速度も大きく異なる．これらのことから，電極 に誘引される粒子量が流動形成に影響を与えていると考え られる. 電極に誘引される粒子量と, 定電場時間の関係は, $T_{d}$ が十分に確保された(a) (c)において粒子量は多く, 粒子量 には密接な関係があると考えられる。しかしながら，(d)，(e) において，(d)は $T_{d}$ が短いにも関わらず粒子量が多く示され る場合も観察されている。定電場時間だけでなく，立ち上が り，立ち下がり時間も含む電場作用時間 $T_{w}$ について検討す ると，粒子量の大小の判断が難しい(c)，(d)もあるが， $T_{d}$ は ほぼ同等であるが $T_{w}$ が大きく異なる(d), (e)においては粒子 量が大きく異なっており $T_{d}$ を含む $T_{w}$ で示される電場が作用 する時間の長さが粒子の誘引を左右する要因のであると考 えられる，すなわち，粒子に電場が作用し，粒子が加速され ることで溶媒をともなう流動が形成されると考えると, 十分 な粒子量が電極近傍に誘引され集積されることで，電場によ り誘起される力が粒子群に作用し, 多くの溶媒をともない, 速度の大きな加速的な流動を形成することが可能になると 考えられる。

すなわち，特異な流動である回転流動形成には，電極近傍 部に十分な量の粒子を誘引可能な定電場時閒の長さが必要 であり，これらにより誘起される加速流動の速度が重要であ ると考えられる。

Table1 Concentration of Particles

\begin{tabular}{|c|c|c|c|c|c|c|}
\hline & $T_{d}$ & $T_{W} \mathrm{~s}$ & $S$ & $f \mathrm{~Hz}$ & $\begin{array}{c}\text { Particl } \\
\mathrm{e}\end{array}$ & $\begin{array}{c}\text { Flow } \\
\text { aspec } \\
t\end{array}$ \\
\hline (a) & 1.0 & 5.0 & 0.4 & 0.1 & 0 & 80 \\
\hline (b) & 1.0 & 1.0 & 0 & 0.5 & 0 & $8 \theta$ \\
\hline (c) & 0.4 & 1.0 & 0.3 & 0.5 & 0 & 88 \\
\hline (d) & 0.2 & 1.0 & 0.4 & 0.5 & $\Delta$ & $\Uparrow \mathcal{E}$ \\
\hline (e) & 0.25 & 0.25 & 0 & 2.0 & $x$ & $\uparrow \uparrow$ \\
\hline
\end{tabular}

\section{4. 結言}

粒子分散型機能性流体に誘起される回転流動形成機構解 明のために，交流電場条件変化，特に周波数変化に対応寸る 電場作用時間ならびに印加波形の立ち上がり角度に着目し， マイクロ PIV 計測により形成される流動特場特性を明らかに した。 さらに，流動場特性を評価する指標として速度場情報 から得られる極大速度情報を用い, 交流電場条件変化による 流動特性変化を明らかにし, 粒子の分散特性との相関を含め, 流動形成機構を解明した。

\section{参考文献}

(1) 赤上,浅利, 藤田, ジャデワン, 梅原, 機論 66-649, $\mathrm{C}(2000), 3168-3173$.

(2) Akagami, N. Umehara, Wear 260 (2006) 345-350.

(3) 監物, 小原, 松平, 機構論, No.04-1(2004), Vol.2,91-92.

(4) 井畑, 監物, 小原, 松平, 機構論,No.06-1(2006), Vol.2,23-24.

(5) H.Obara,Y. Kawai,R. Ibata, Y. Matsudaira, Proc. of ASME FEDSM'07 (2007), FEDSM2007-37191 